\title{
ECG Used Same Lead Indicator
}

National Cancer Institute

\section{Source}

National Cancer Institute. ECG Used Same Lead Indicator. NCI Thesaurus. Code

C119563.

An indication as to whether ECG interval measurements were based on the same lead. 